\title{
Modelling mid-crustal migmatite terrains as feeder zones for granite plutons: the competing dynamics of melt transfer by bulk versus porous flow
}

\author{
Sakiko N. Olsen, Bruce D. Marsh and Lukas P. Baumgartner
}

\begin{abstract}
The common association of mid-crustal migmatites with an upper-level granite pluton could indicate that the migmatites are a feeder zone for the pluton. If magma from a deeper level pervasively intrudes a high temperature metamorphic complex, most of the intruded magma would not freeze because of the prevailing temperature. The interaction between the magma and country rocks, which could include partial melting and crystallisation of the magma passing through, would modify magma to a more granitic composition, as found in the higher-level pluton.

The physical aspect of the magma transport through such a hot feeder zone is modelled by introducing a dimensionless melt transport (MT) number, which is the ratio of the rate of melt movement caused by the bulk flow of the entire mass (melt+solid) to that of porous media flow of melt only through the solid framework. The MT number is strongly dependent on the melt content of the melt-rich zone (MRZ), the diameter of the MRZ and typical particle size in the MRZ.

The 300-Ma, diatexitic, Lauterbrunnen migmatites (LM) in the Aar massif, Swiss Alps, may be such a feeder zone for the nearby 303-Ma Gastern granite (GG). The chemical and field evidence indicates that the LM formed by an intrusion of intermediate composition magma, which interacted with country rocks to produce a magma of GG composition.
\end{abstract}

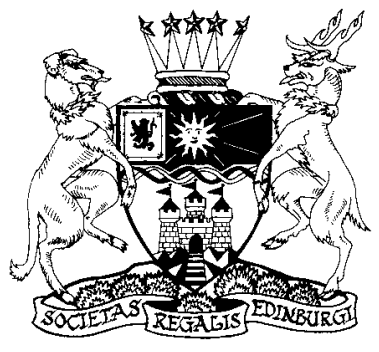

KEY WORDS: Aar massif, Diatexite, magma, dimensionless number.

It is generally argued that the magmas for most upper-crustal granite plutons have their sources in the lower crust (e.g. Clemens et al. 1997; Petford et al. 2000), and therefore, the formation of these plutons must involve magma generation deeper in the crust, transport through the crust and uppercrustal level emplacement (e.g. Brown 1994). The present authors will address the second stage, the long-range transport of magma from deep to shallow crustal levels. The two, end-member models most often advocated for this transport are transport through a dyke and diapiric ascent of a magma body. Field evidence is frequently not definitive (e.g. Petford et al. 2000); for example, dyke swarms of granitic compositions are uncommon, and structures attributed to diapiric ascent could be related to emplacement instead. The present authors describe a model of mid-crustal migmatites as feeder zones, in which the magma transport is by pervasive, and macroscopic, porous-media flow (see also Petford \& Koenders 1998; Brown \& Solar 1999; Weinberg 1999) through country rocks which have already been warmed to nearly solidus temperatures.

Mid-crustal migmatites are an enigma in and of themselves. In situ partial-melting is generally proposed for their genesis (e.g. Brown 1994; Sawyer 1996). P-T conditions for the migmatite formation (Fig. 1) are consistent with nearly watersaturated melting of common rocks (e.g. Wyllie \& Tuttle 1964; Thompson 1999), but such melting requires both a source and a transport mechanism for a large volume of free water, neither of which have been unequivocally documented for the mid-crust. Dry melting of these rocks requires much higher temperatures. Alternatively, fluid-absent melting of common metamorphic minerals (e.g. muscovite and biotite) may provide the melt, and P-T estimates for the mid-crustal migmatites are compatible with such melting, especially muscovite dehydration melting (Fig. 1), but many of the migmatites contain neither muscovite nor a possible byproduct of muscovite-dehydration melting such as aluminosilicate. Moreover, typical geothermal gradients alone do not provide temperatures high enough for any dehydration melting, especially of biotite (Fig. 1). Regardless of the mechanism, an extra heat source seems necessary for the significant melt generation at the crustal levels of these migmatites. If the temperatures obtained from geothermometers are underestimated, for example, because of partial re-equilibration of cation exchange reactions during cooling (Frost \& Chacko 1989), P-T conditions would deviate even farther from what are compatible with geothermal gradients. On the other hand, $\mathrm{P}-\mathrm{T}$ estimates and resulting geothermal gradients are consistent with seismic evidence showing that only a small portion of the crust comprises melt. Hence, melting must generally occur because of local heating above the solidus (e.g. Marsh 1984). Many sources, such as mantle heat, or magma and radiogenic heat, have been proposed for this necessary extra heat (e.g. see Huerta et al. 1996; Jamieson et al. 1998; Thompson 1999).

In this model, the thermal input comes from a magma of more mafic composition which formed at a deeper level. The unavoidable dynamic expression of the presence of this magma as an active mobile body is the development of a large-scale complex of veins and dykes above. The net thermal effect of this complex is to slightly, but pervasively, preheat the overlying high-grade metamorphic complex to a thermal state conducive to the survival of small parcels of melt for long periods of time, which would make upward transfer of melt through such a complex possible. The critical thermal condition necessary for melt persistence is that the contact (i.e. dykelet/wall rock) temperature be at or above the solidus of the melt. This may be achieved at least in part by the 


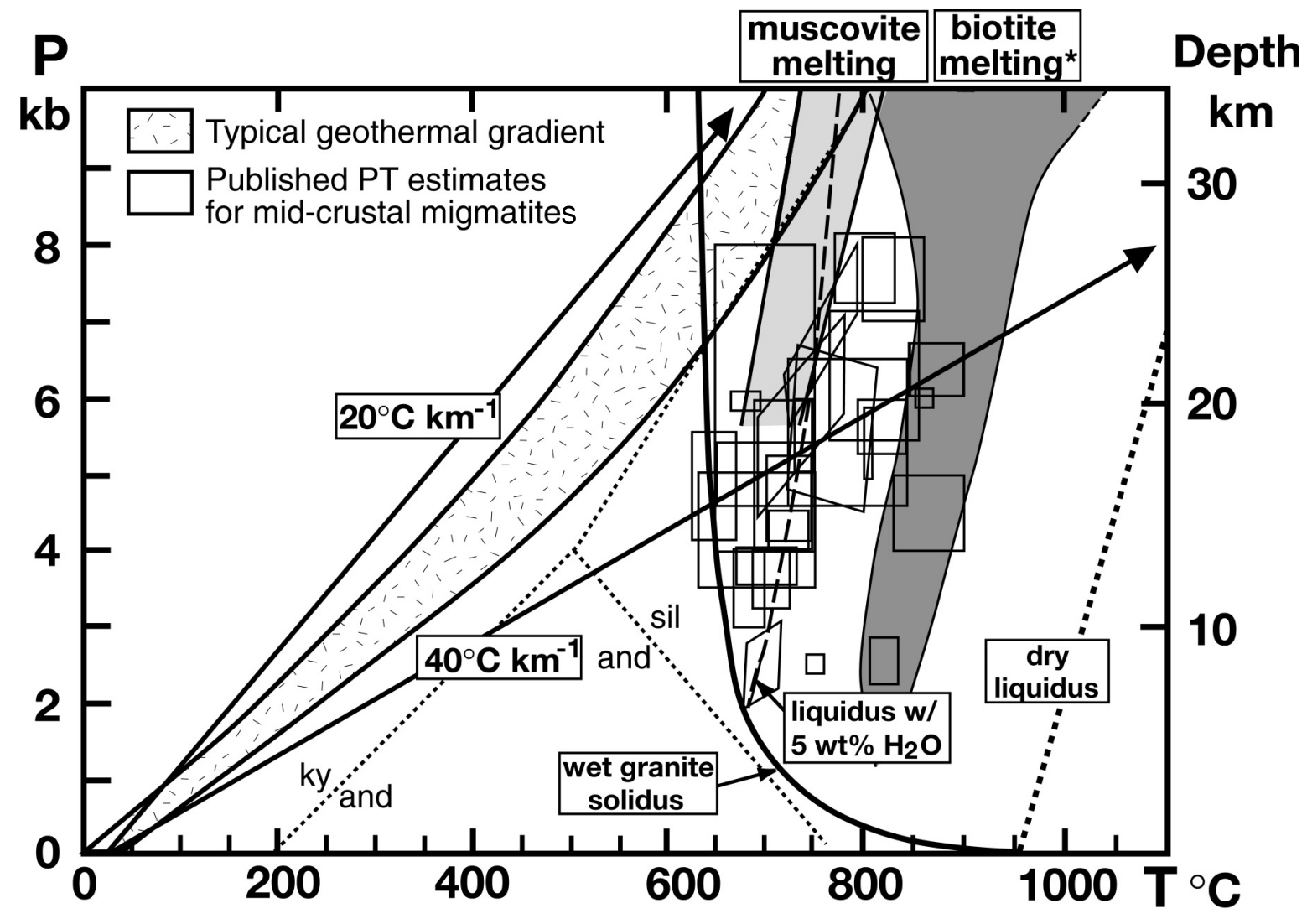

* 10 to $60 \%$ melt

Figure 1 Geothermal gradients, experimental melting reactions and published P-T conditions for mid-crustal migmatites. Sources of data: Geothermal gradient (Brown \& Mussett 1993). Experimental data: Aluminosilicates phase relations (Holdaway 1971). Granite melting curves, dry and wet (Ebadi \& Johannes 1991). $\mathrm{H}_{2} \mathrm{O}$ contents in granitic melt (Holz \& Johannes 1994). Biotite fluid-absent melting reaction (Vielzeuf \& Montel 1994; Montel \& Vielzeuf 1997). Muscovite fluid-absent melting reaction (Patino-Douce \& Harris 1998). P-T estimates for migmatites: Antarctica, Brattstrand Bluffs (Fitzsimons 1996). Antarctica, Taylor Valley (Allibone \& Norris 1992). Antarctica, Victoria Land (Palmeri 1997). Argentina, Sierra Pampeana (Rapela et al. 2002). Australia, Cooma (Ellis \& Obata 1992). Australia, Mt Stafford (Greenfield et al. 1996). Australia, Reynolds Range (Dirks \& Hand 1991). Australia, Wuluma Hills (Sawyer et al. 1999). Finland, Turku area (Mengel et al. 2001). Finland, Rantasalmi-Sulkava area (Gupta \& Johannes 1986). France, St Malo (Brown 1979). Italy, Sardinia (Cruciana et al. 2001). Japan, Higo district (Obata et al. 1994). Nambia (Jung et al. 1998). Spain, Iberian Massif (Viruete 1999). Spain, Trois Seigneurs, Pyranees (Wickham 1987). Sweden, Arvika (Henkes \& Johannes 1981). Switzerland, Aar Massif (Olsen et al. 2000). Switzerland, Black Forest (Mazurek 1992). USA, Massachusetts (Thomson 2001)

generation of melt that has a solidus lower than that of its parent rock (e.g. Leitch \& Weinberg 2002). An explicit, quantitative formulation of these conditions is given in Marsh (1989; e.g. see Eqn. 57).

The large scale but low amplitude of this thermal anomaly means that this complex has a long-term thermal inertia, which facilitates extensive thermal and chemical interactions during melt development on small scales within the intruded host rocks. Such interactions can form a magma of modified composition which, in turn, intrudes the upper crust as a granite pluton. In this paper, the authors present a first step in quantifying this general model of mid-crustal migmatites as feeder-zones by introducing a dimensionless number, MT, for melt transport, which is the ratio of the rate of melt movement caused by the bulk flow of the entire mass (melt + solid) to that of porous media flow of melt only through the solid framework. Finally, they apply it to a geologic example located in the Swiss Alps. In a related work, Leitch \& Weinberg (2002) have examined the specific thermal problem of injecting melt segregated from an underlying partially melted zone upward through dyke-like channels into a region whose temperature is above the solidus of the injecting melt. In contrast to the present authors' treatment, they did not consider the dynamic stability of this assumed flow relative to both a Darcian flow and a regional flow, as is treated here.

\section{Modelling melt transport through a feeder zone}

For this feeder zone model to be valid, the melt transport must be predominantly, if not solely, by porous flow (Fig. 2a) in which the melt percolates through the interstices of a solid framework in a melt-rich zone (MRZ) to feed an overlying pluton. This is one of the two end-member transport mechanisms for the melt. The other is a bulk mass flow of the entire MRZ caused by gross buoyancy (bulk flow: Fig. 2b). The present authors evaluate the relative importance of these flows by using the MT number as defined below.

The overall rate of total melt flux, $\mathrm{V}_{\mathrm{m}}$, can be expressed as

$$
V_{m}=(1-\varphi) V_{s}-\left[\frac{K_{D}}{\mu_{2}}\right]\left\{\frac{\partial P}{\partial z}+\Delta \rho_{2} g\right\}
$$




\section{(a) Porous flow: MT\# $<1$}

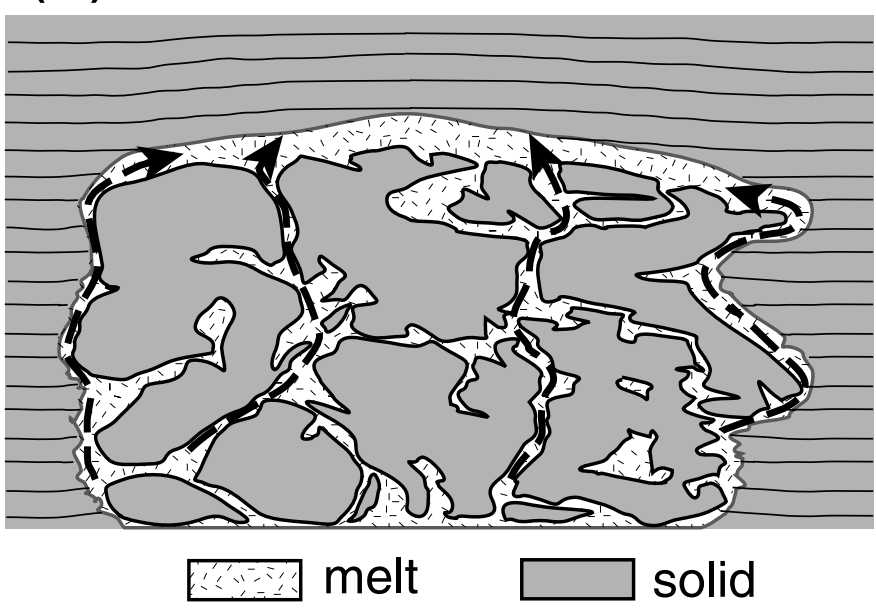

(b) Bulk flow: MT\# >1

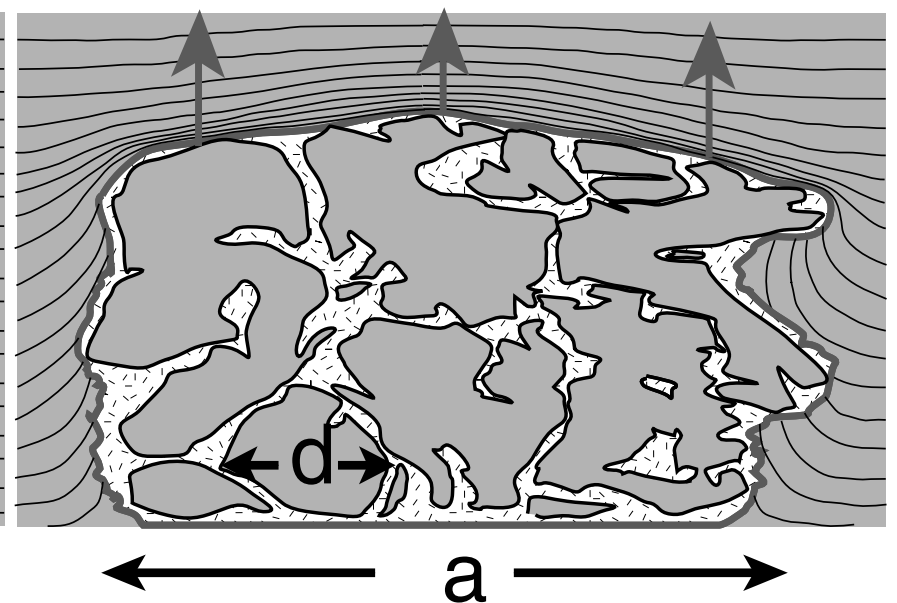

Figure 2 Models of the melt transport mechanisms.

Table 1 Definitions of the parameters in Equations 1 to 6, values used in calculations and their sources: (MRZ) melt-rich zone.

\begin{tabular}{|c|c|c|c|}
\hline Symbol & Explanation & $\begin{array}{l}\text { Values used for } \\
\text { Figures } 3 \text { and } 4 \text { unless } \\
\text { otherwise specified }\end{array}$ & Source \\
\hline $\mathrm{V}_{\mathrm{m}}$ & Overall velocity of melt & & \\
\hline $\mathrm{V}_{\mathrm{s}}$ & Velocity of MRZ (solid + melt) & & \\
\hline $\mathrm{K}_{\mathrm{D}}$ & Permeability & & \\
\hline $\mathrm{P}$ & Pressure & & \\
\hline $\mathrm{z}$ & Distance & & \\
\hline $\mathrm{g}$ & Gravitational acceleration & & \\
\hline $\mathrm{e}$ & Porosity $(=1-\varphi)$ & & \\
\hline$\varphi$ & Crystallinity & & \\
\hline $\mathrm{C}_{1}$ & Viscosity constant & $2 \cdot 5 / 9$ & Marsh (1982) \\
\hline $\mathrm{C}_{\mathrm{K}}$ & Permeability constant & 100 & Marsh (2002) \\
\hline $\mathrm{a}$ & Diameter of MRZ & & \\
\hline $\mathrm{d}$ & Diameter of grains/particles & & \\
\hline$\mu_{1}$ & Viscosity of hot country rocks & $10^{18}$ poises $\left(=10^{17} \mathrm{~Pa} \mathrm{~s}\right)$ & Marsh (1984) \\
\hline$\mu_{2}$ & Viscosity of melt & $10^{5}$ poises $\left(=10^{4} \mathrm{~Pa} \mathrm{~s}\right)$ & $\begin{array}{c}\text { Marsh (2002): } \\
\text { calculated using MELTS } \\
\text { (Ghiorso \& Sack 1995) }\end{array}$ \\
\hline$\Delta \rho_{1}$ & $\begin{array}{l}\text { Density difference between } \\
\text { MRZ and country rocks }\end{array}$ & $\begin{array}{c}\text { Country rock }=2.85 \\
(\mathrm{MRZ}=2 \cdot 68 @ \mathrm{e}=0 \cdot 5)\end{array}$ & Miller et al. (1988) \\
\hline$\Delta \rho_{2}$ & $\begin{array}{l}\text { Density difference between } \\
\text { solid and melt in MRZ }\end{array}$ & Melt density $=2 \cdot 5$ & Marsh (2002) \\
\hline
\end{tabular}

in which the first term on the right-hand side of the equation represents bulk flow, and the remaining term represents porous flow after Darcy's law (e.g. Phillips 1991: see Table 1 for the parameters in Equations 1-6). The first term, that for bulk flow transport, is the product of the 'regional' melt content and a measure of the rate of upward motion $\left(\mathrm{V}_{\mathrm{s}}\right)$ of the rock containing the melt. Since this upward motion is caused by large-scale buoyancy or a gravitational instability, regardless of the exact form of the flow, $\mathrm{V}_{\mathrm{s}}$ will be proportional to Stokes' Law velocity (e.g. Leal 1992, p. 230), within the value of an unknown constant of numerical magnitude of near unity (i.e. $\left.\mathrm{C}_{1} \sim 1\right)$. Therefore,

$$
V_{s}=C_{1}\left[\frac{\Delta \rho_{1} g a^{2}}{\mu_{1}}\right]
$$

The rate of porous flow, on the other hand, is heavily dependent on the local permeability, which is estimated from the Blake-Kozeny-Carman equation (e.g. Bird et al. 1960),

$$
K_{D}=\left[\frac{d^{2} e^{3}}{(1-e)^{2} C_{K}}\right]
$$

so that the net transport is

$$
\begin{aligned}
& V_{m}=(1-\varphi) C_{1}\left[\frac{\Delta \rho_{1} g a^{2}}{\mu_{1}}\right] \\
&-\frac{1}{\mu_{2}}\left[\frac{d^{2} e^{3}}{(1-e)^{2} C_{K}}\right]\left\{\frac{\partial P}{\partial z}+\Delta \rho_{2} g\right\}
\end{aligned}
$$


(a)

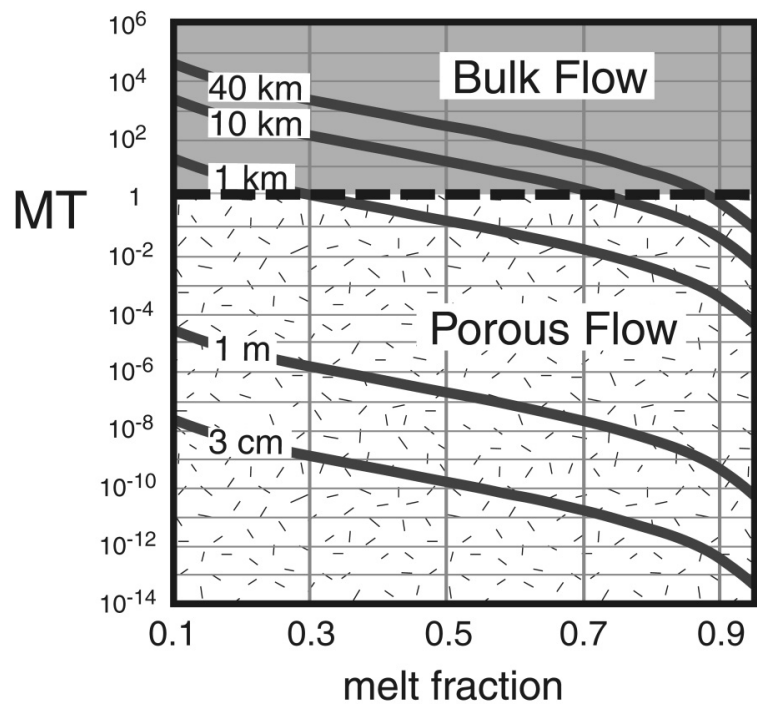

(c)

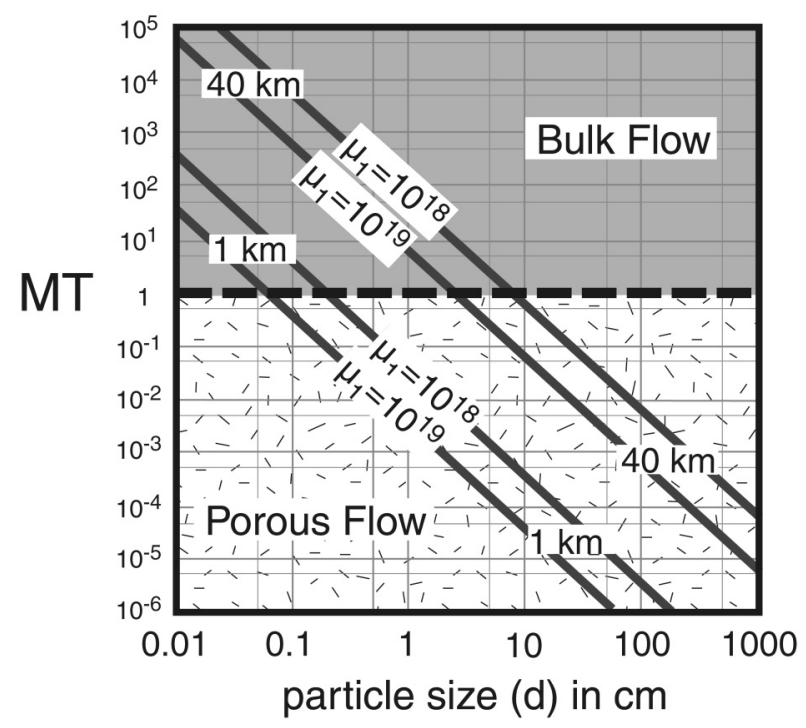

(b)

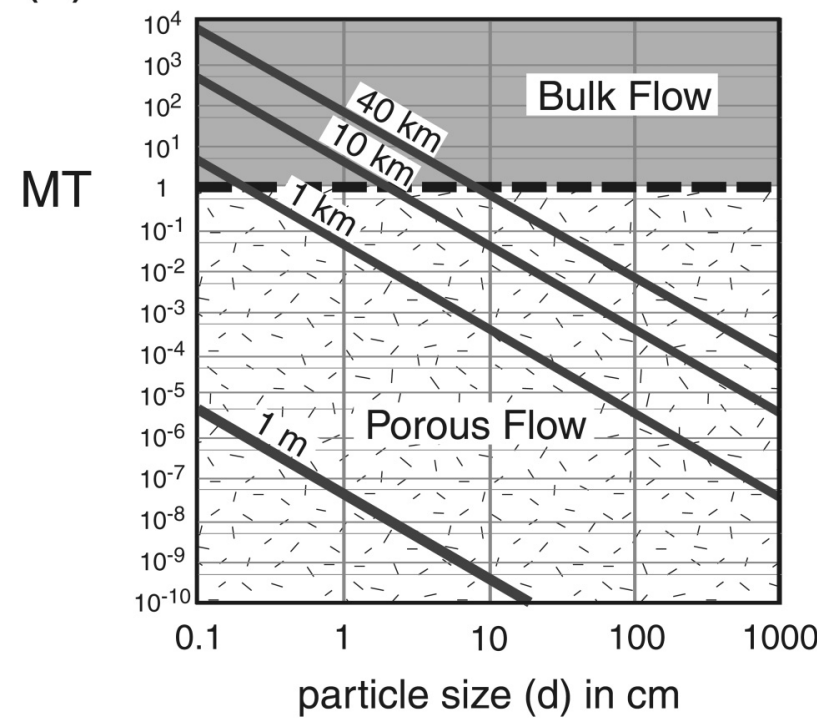

(d)

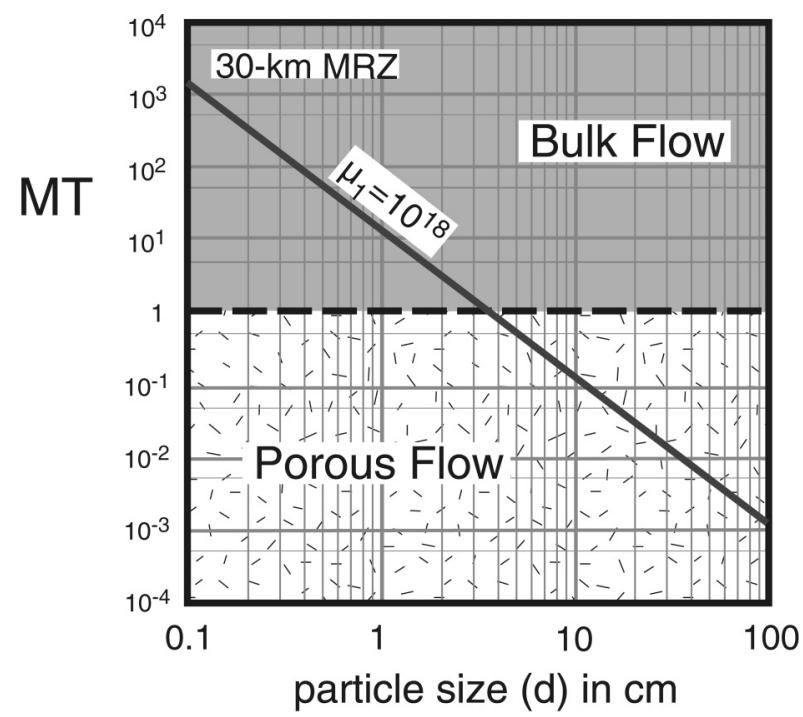

Figure 3 The results of the melt transport (MT) number calculations. For the values of the parameters used, see Table 1. (a) Effect of pluton/melt-rich zone (MRZ) size (e.g. $40 \mathrm{~km}$ ) on MT number at particle size of $3 \mathrm{~mm}$ and $\mu_{1}=10^{18}$ poise. (b) Effect of MRZ/particle size on MT number at 0.4 melt fraction. (c) Effect of viscosity and MRZ size on MT number at 0.4 melt fraction. (d) Melt transport number calculation for the LM as a $30 \mathrm{~km}$ MRZ at 0.5 melt fraction (see text).

The intrinsic permeability is a function of the pore size. The use of particle size, rather than pore or channel size, in Equation 3 is justified because the intrinsic permeability is directly linked to the overall scale of the granularity of the solids regardless of actual size (e.g. Bird et al. 1960). This is because the drag exerted by the fluid against the surface of the solids controls the rate of flow.

The present authors define a melt transport (MT) number, as the ratio of the two terms in Equation 4, i.e.

$$
M T=\left\{\frac{(1-\varphi) C_{1}\left[\frac{\Delta \rho_{1} g a^{2}}{\mu_{1}}\right]}{\frac{1}{\mu_{2}}\left[\frac{d^{2} e^{3}}{(1-e)^{2} C_{K}}\right]\left\{\frac{\partial P}{\partial z}+\Delta \rho_{2} g\right\}}\right\}
$$

The porous flow is driven by either density (or buoyancy) differences $(\Delta \rho \mathrm{g})$ or a local pressure gradient $(\partial \mathrm{P} / \partial \mathrm{z})$, or both. For now, the authors assume $\partial P / \partial z \approx 0$ for convenience, but the assumption will be justified later. Then,

$$
M T=C_{1} C_{K}\left[\frac{(1-e)}{e}\right]^{2}\left[\frac{\Delta \rho_{1}}{\Delta \rho_{2}}\right]\left[\frac{\mu_{2}}{\mu_{1}}\right]\left[\frac{a}{d}\right]^{2}
$$

The MT number is an indicator of the relative contributions of the flows by the two transport mechanisms to the overall movement of the melt. If MT $>1$, melt transport is dominated by bulk flow. If $\mathrm{MT}<1$, melt transport is dominated by porous flow. If $\mathrm{MT} \approx 1$, both mechanisms contribute subequally to the overall flow.

Sample calculations show that the MT number is strongly dependent on melt fraction (e), the diameter (a) of the MRZ 
(a)
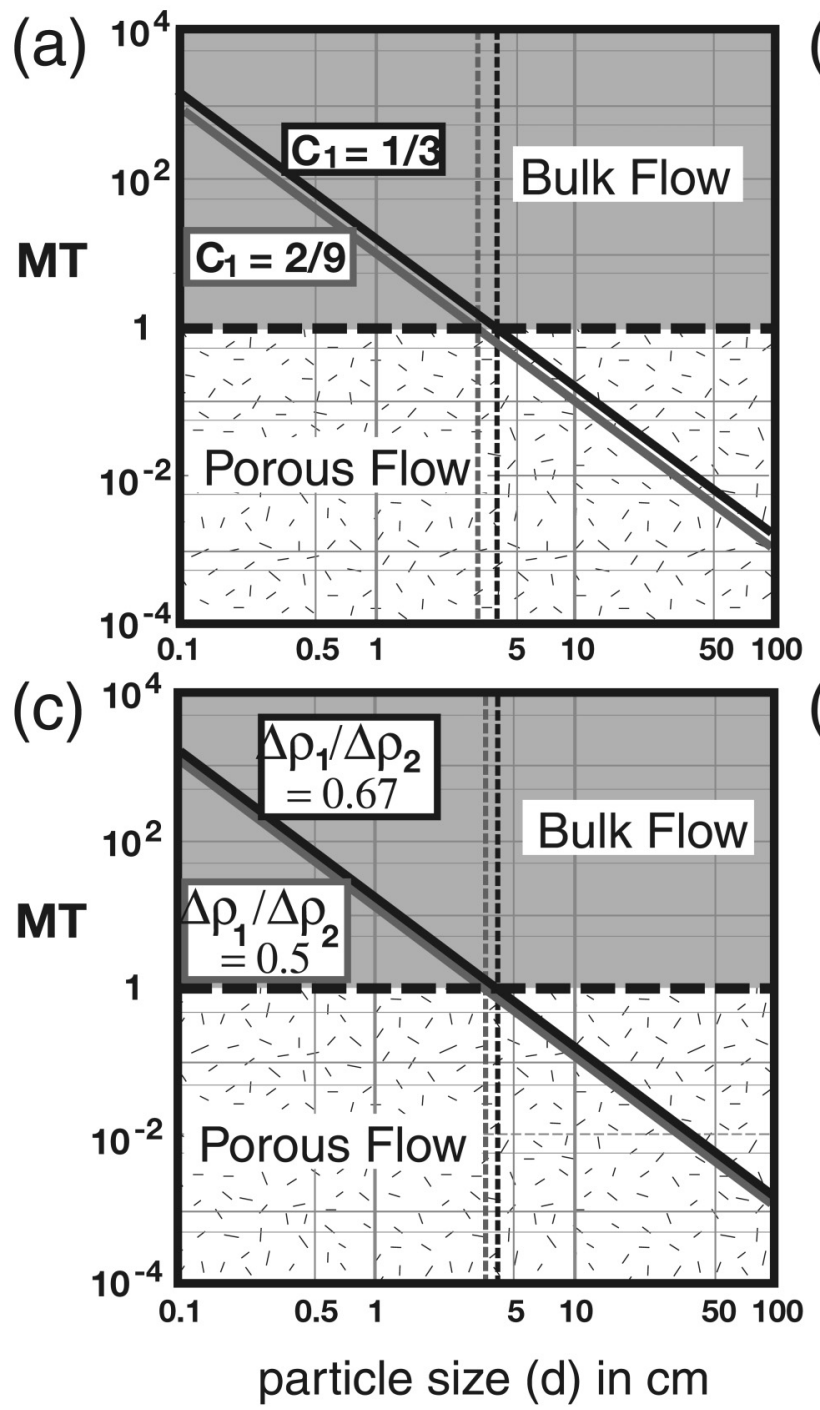

(b)

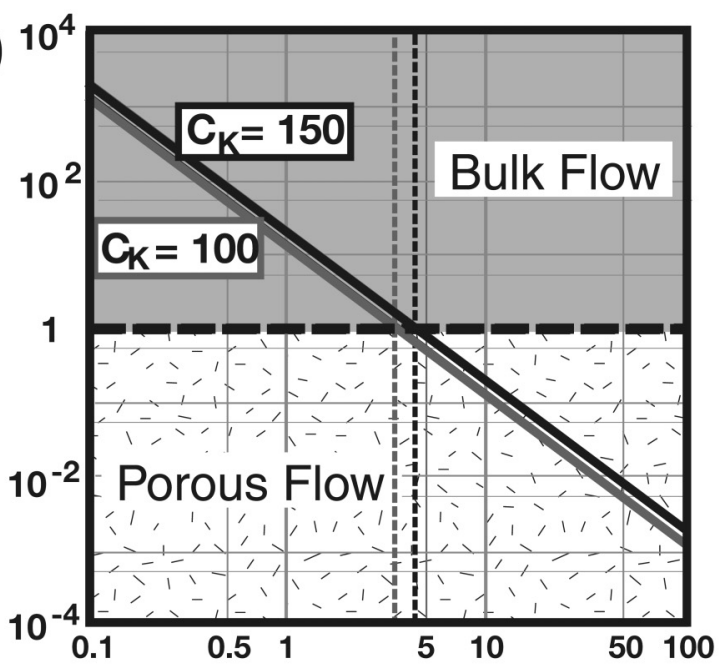

(d)

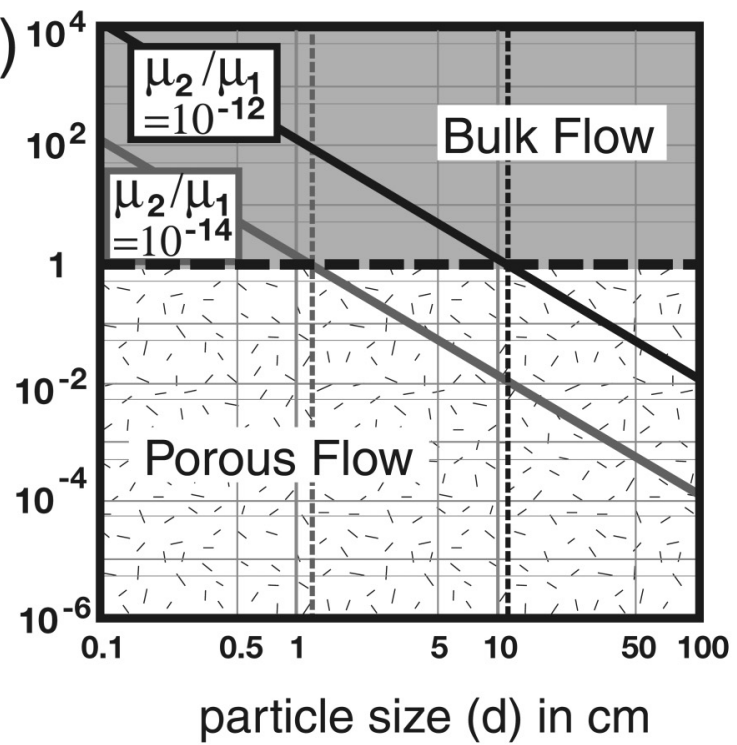

Figure 4 Further results of the melt transport (MT) number calculations showing the effects of varied values for the parameters on MT number at 0.5 melt fraction for a $30 \mathrm{~km}$ melt-rich zone: effects of: (a) viscosity constant; (b) permeability constant; (c) density difference; and (d) viscosity difference. For the values of the other parameters used, see Table 1.

and particle size (d), but less so on all other parameters (Figs 3 $\& 4$; also Table 1). If the particle size is $\sim 3 \mathrm{~mm}$, the size of coarse crystals, transport by bulk flow is favoured for a large MRZ (10-40 km), except at very high melt fractions (Fig. 3a). As the size of the MRZ decreases, however, porous flow becomes more important. On the scale of typical migmatite neosomes, porous flow dominates at all melt fractions. Melt transport also depends strongly on particle size (Fig. 3b-d): as particle size increases, local drag (per unit volume of melt) is reduced, so that even for a large MRZ porous flow becomes dominant. For example, at a melt fraction of $0 \cdot 4$, porous flow becomes dominant in a $40 \mathrm{~km} \mathrm{MRZ} \mathrm{at} \mathrm{a} \mathrm{particle} \mathrm{size} \mathrm{of} \sim 8 \mathrm{~cm}$ (Fig. 3b). Melt transfer through dykes may be considered to be the extreme case of very large particle size.

Other parameters, as long as their values stay within reasonable ranges, as discussed below, do not significantly affect the critical particle size for the cross-over from bulk flow controlled by buoyancy to flow controlled by porous media. Varied values are tested in Figure 4 for a MRZ of $30 \mathrm{~km}$ at a melt fraction of 0.5 , which are appropriate for the Alpine example discussed below (also see Fig. $3 d$ ). If $\mathrm{C}_{1}$, the viscosity coefficient, is changed from 1/3 (typical for a gas bubble in a viscous fluid) to $2 / 9$ (for a solid sphere in a viscous fluid, e.g. Marsh 1982), the critical particle size decreases from 3.9 to
$3.2 \mathrm{~cm}$, or a size change of $\sim 15 \%$ (Fig. $4 \mathrm{a}$ ). For granular materials, $\mathrm{C}_{\mathrm{K}}$, the permeability coefficient, of 150 is used in the Blake-Kozeny-Carman equation, but a coefficient of 100 fits data for the partially molten media better (Marsh 2002). The difference between these values of $\mathrm{C}_{\mathrm{K}}$ corresponds to a difference of $\sim 1 \mathrm{~cm}(\sim 25 \%$ diameter change $)$ in critical particle size (Fig. 4b). The density difference is constrained by the melt fraction because the density of MRZ is a linear sum of the densities for solid and melt. The ratio of density differences can be varied arbitrarily but the effect is insignificant (Fig. 4c). The viscosity of the country rocks $\left(\mu_{1}\right)$ is probably the least known of all parameters in Equation 6. The present authors constrained the viscosity to a representative value of $10^{18}$ poises by considering how hot crust responds to deformation (e.g. Wernicke et al. 2000). A lower bound comes from the viscosity of basaltic rock near its solidus, which was found by Sakuma (1953) to be $\sim 10^{15}$ poises, but holocrystalline crustal rocks must be more viscous than this. An upper bound comes from the treatment and discussion of folding of cool crustal rocks by Biot (1961) and Johnson \& Fletcher (1994; see p. 30), and the flexural rigidity of the crust from glacial rebound studies (e.g. Cathles 1975), which altogether suggest a value of $\sim 10^{22}-10^{23}$ poise. The viscosity of the melt $\left(\mu_{2}\right)$ is calculated for a dacite with $\mathrm{SiO}_{2}$ content of $63 \mathrm{wt} . \%$ (Table 1). The 
(a)

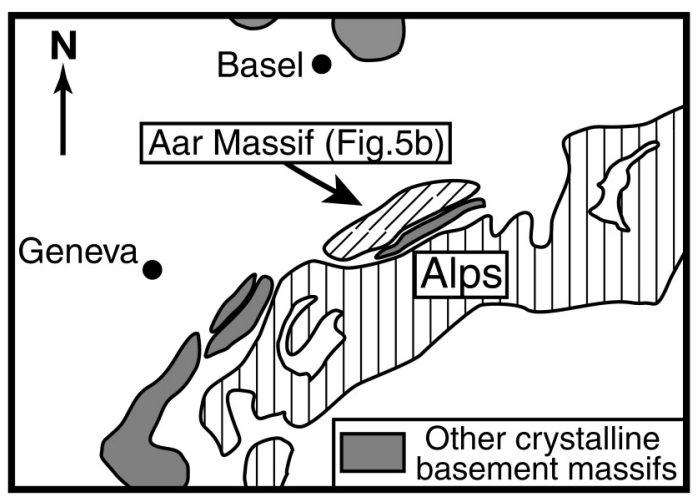

Explanations for Fig. 5b

iz: Innertkirchen-Lauterbrunnen zone

E Erstfeld gneiss zone

TI Other gneisses, sediments, volcanics

G Gastern granite

I. Other Variscan intrusives

(b) Lauterbrunnen (LM)

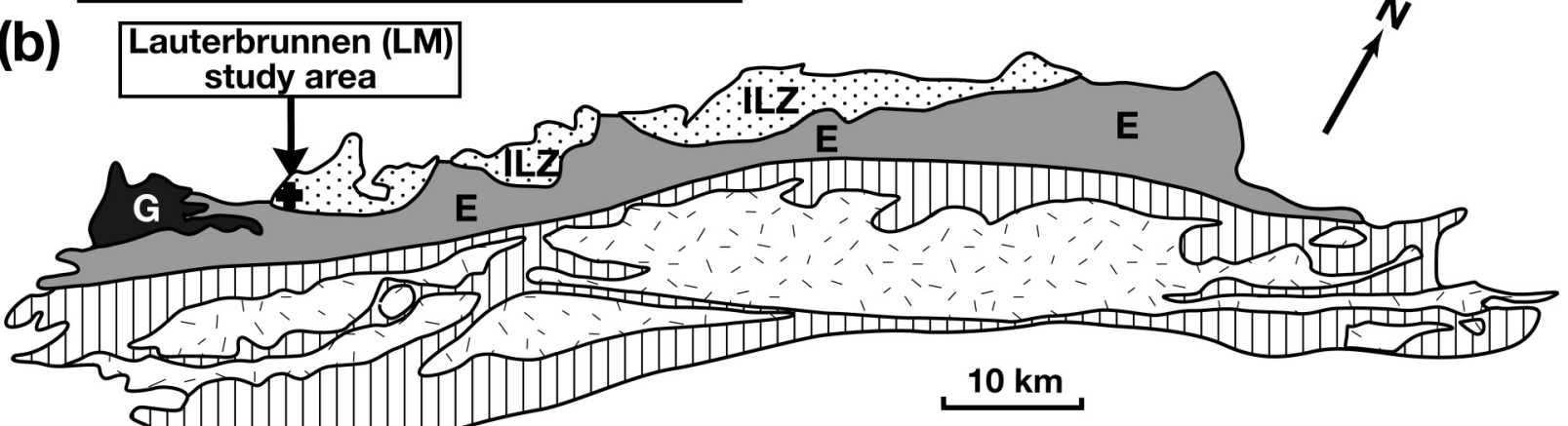
(1993) showing the study area.

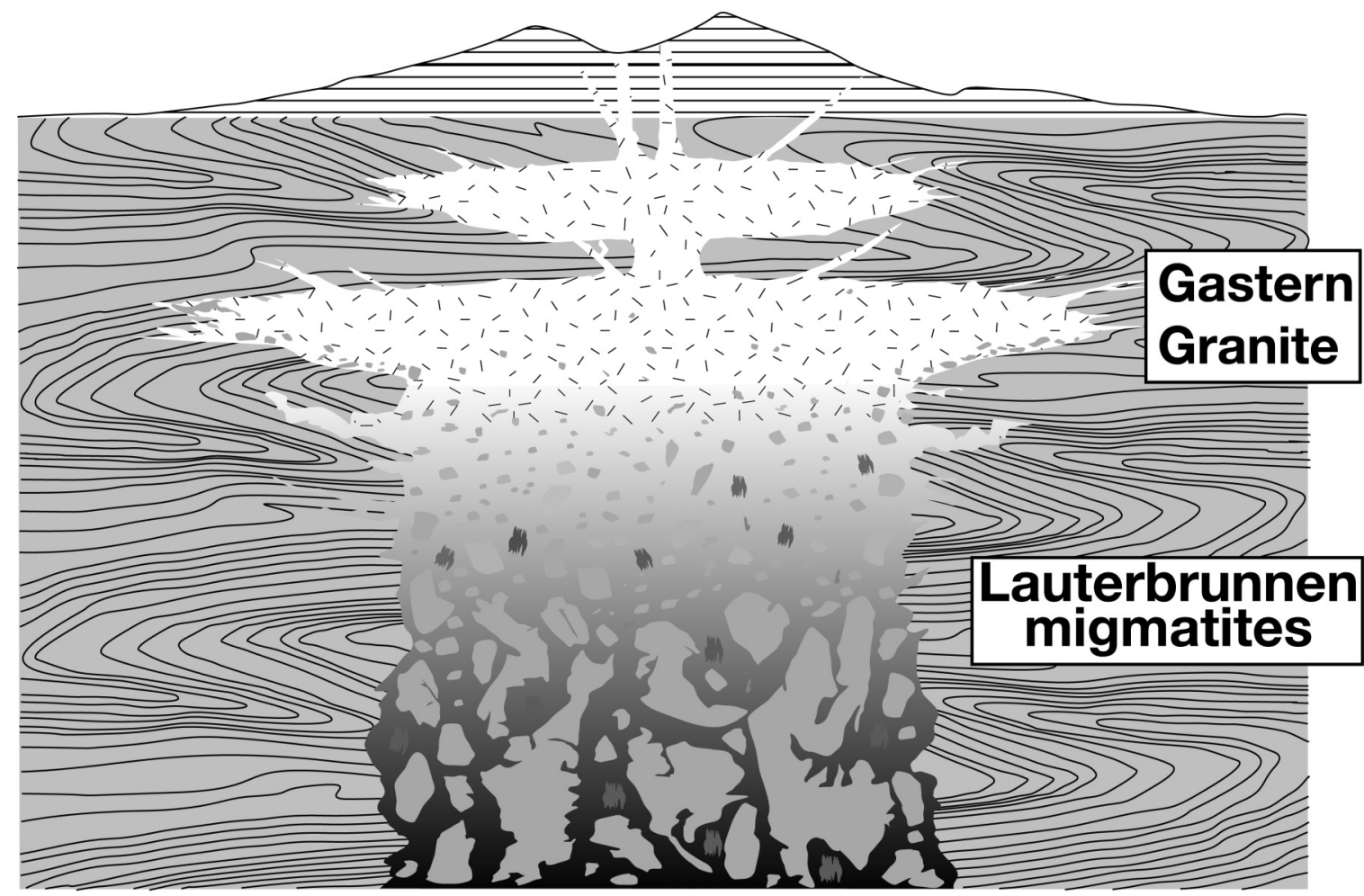

Figure 6 A schematic sketch of the Lauterbrunnen migmatites and Gastern granite showing their inferred relationship.

viscosity difference does affect the result significantly (Fig. 4d). Use of $10^{19}$ instead of $10^{18}$ for $\mu_{1}$ for MRZs at a melt fraction of 0.4 reduced the critical particle size by $\sim 68 \%$ (Fig. $3 \mathrm{c}$ ). The use of an even larger value for $\mu_{1}$ (e.g. $\sim 10^{25}$ poises: Clemens et al. 1997) greatly favours porous flow, because the MRZ becomes virtually immobile (no bulk flow). The present authors emphasise, however, that such a large 'regional' crustal viscosity corresponding to the cool upper crust, as might be found, for example, through crustal flexure modelling, is clearly inappropriate for the locally heated mid-level crust.

Thus far, $\partial P / \partial z=0$, or no pressure gradient, has been assumed. However, a local pressure gradient, for example, one caused by regional shearing (e.g. Hollister \& Crawford 1986) or a volume change consequent to melting (e.g. Brown 1994), could be an important driving force for melt movement. All of 

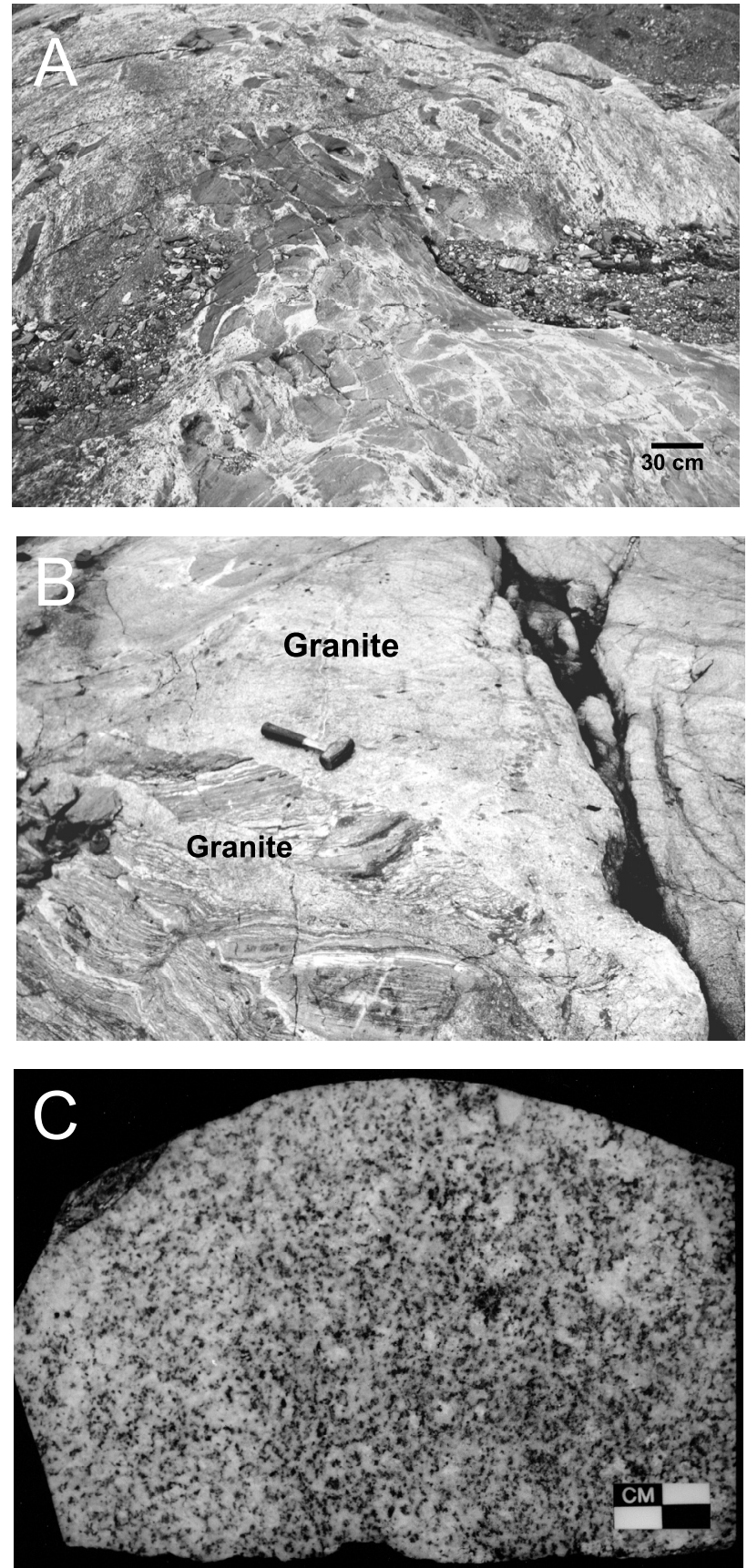

Figure 7 Field and sample photos: (a) a large, fractured enclave (lower half) and heterogeneous matrix (upper half) of the Lauterbrunnen migmatites (LM); (b) the Gastern granite (top) in intrusive contact with the country rocks considered to be an equivalent of LM (lower left); and (c) a slab of Sample LA14.

the local pressure gradients produced by these processes enhance porous media flow. Thus, the balance is shifted further in favour of porous flow, so that the above conclusions concerning porous flow should still be generally valid: the feeder zone model is supported by the feasibility of porous media flow under geologically reasonable conditions. The effect of pressure gradient can also be gauged by varying the density difference, which exerts the same driving force as pressure gradient (Equation 4), but this does not significantly change the results (Fig. 4c).

\section{Geologic example: the Lauterbrunnen migmatites}

A possible geologic example of the present model for the feeder zone is the Lauterbrunnen migmatites (LM) in the Aar massif
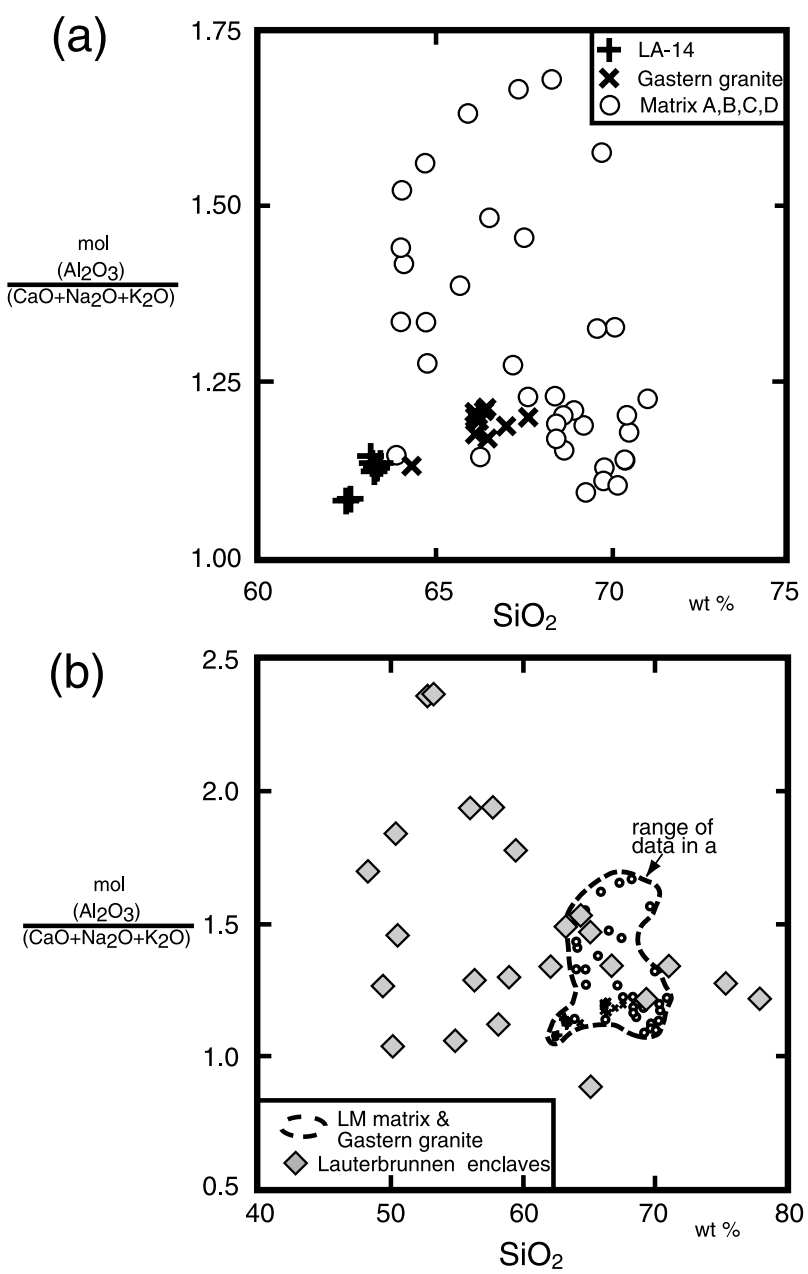

Figure 8 (a) Aluminium indices versus $\mathrm{SiO}_{2}$ contents of the Lauterbrunnen migmatites (LM) matrix, Gastern granite and (b) LM enclaves. Matrices A, B, C and D correspond to zones A, B, C and D in Figure 9, which have somewhat different lithologies (see Rutishauser 1972).

in the Central Swiss Alps (Fig. 5), which may be the feeder zone for the nearby Gastern granite (GG) (Fig. 6). The LM are typical mid-crustal migmatites. P-T conditions are constrained to from 650 to $750^{\circ} \mathrm{C}$ at $5-6 \mathrm{~kb}$ by the mineral assemblage present, which has at one time included abundant cordierite. Precise thermo-barometric determinations are not possible because of extensive greenschist facies mineral alteration during subsequent Alpine metamorphism. The U-Pb zircon ages show that the LM and GG are basically coeval $(289 \pm 9 \cdot 4 \mathrm{Ma}$, Olsen et al. 2000, and $303 \pm 4 \mathrm{Ma}$, Schaltegger 1993, respectively).

The LM comprise a weakly foliated, extremely heterogeneous, biotite-two-feldspar-quartz matrix containing numerous enclaves, which are a few centimetres to $>30 \mathrm{~m}$ in size (Fig. 7a). The enclaves consist of amphibolite, calc-silicate hornfels, marble and biotite-quartz-feldspar gneiss. The LM matrix has peraluminous granitic to granodioritic compositions (Fig. 8a) and its proportion varies locally from 50\% to nearly $100 \%$ of the outcrop area (Fig. 9). The enclave compositions are much more varied than those of the matrix, and many are refractory (Fig. 8b). The GG (Fig. 7b) is a homogeneous granite that cross-cuts the foliation of the country rocks, which are considered to be equivalent to the LM, but the chemical and isotopic compositions of the GG are indistinguishable from the average LM matrix (Fig. 8a). The GG composition is also reasonable as a product of the LM parental magma (see below), which has been modified by interactions with rocks similar to the LM enclaves. 

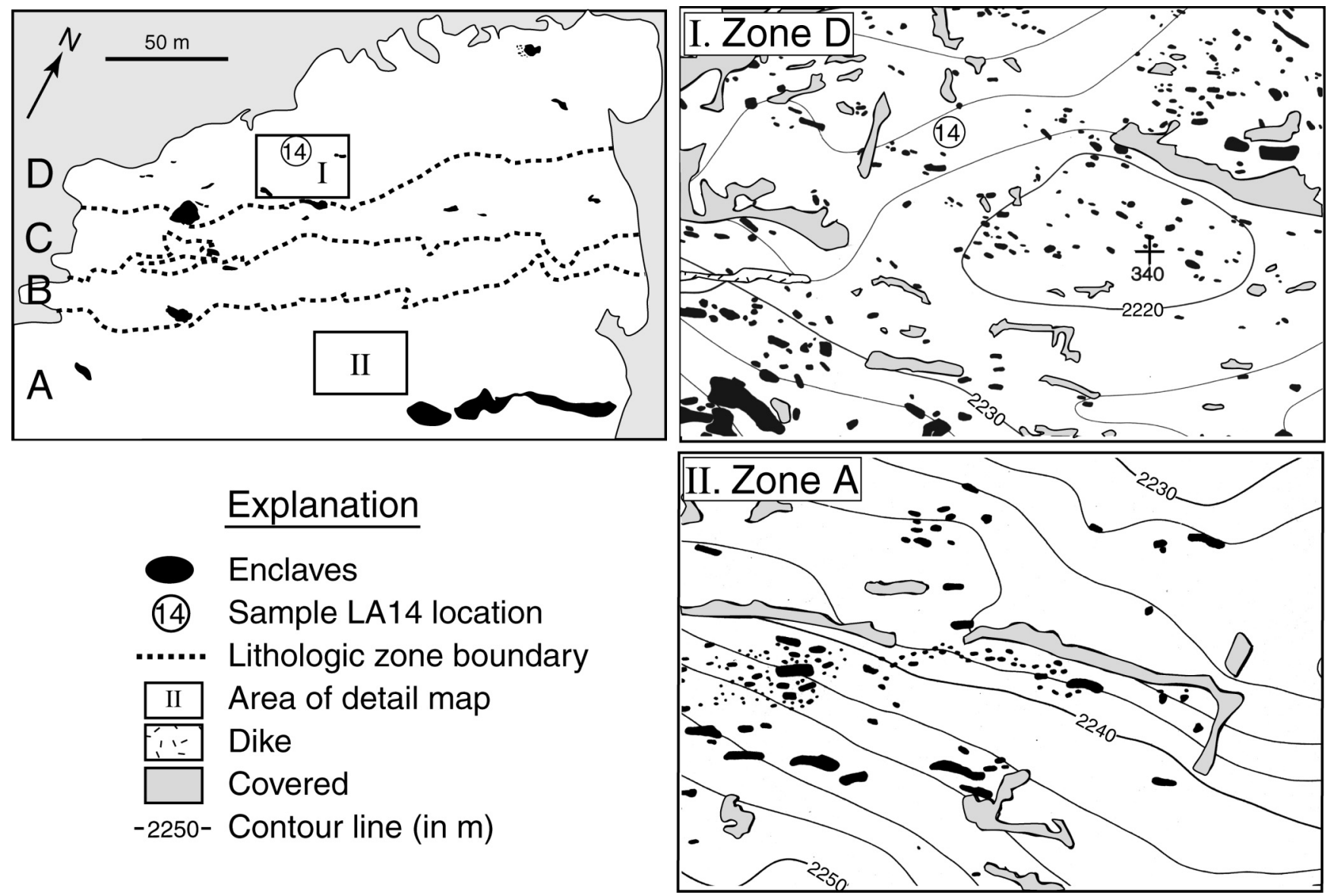

Figure 9 A simplified map of the Lauterbrunnen outcrop (upper left) after Rutishauser (1972): maps I and II show details from Rutishauser.

The evidence for a parental magma in the LM from a deep level is provided by a sample from an area of matrix that is lensoid in shape, metre-scale and uncharacteristically homogeneous in an otherwise heterogeneous matrix (Sample LA14: Fig. 7c; also Fig. 9). LA14 is interpreted to be a sample of 'melt', which is the closest in composition to the intrusive parental magma. LA14 is unique among all LM matrix samples: first, LA14 is homogeneous, unlike the typical, extremely heterogeneous, LM matrix (compare Fig. 7a and c); secondly, LA14 has abundant magmatic zircons with nearly concordant ages of $289 \pm 9 \cdot 4 \mathrm{Ma}$, whilst other LM matrix samples have zircons with highly discordant ages (Olsen et al. 2000); and thirdly, the LA14 composition is the least silicic of all LM matrix samples (Fig. 8a). LA14 composition at 63 wt.\% $\mathrm{SiO}_{2}$ is not appropriate as an in situ melt at the crustal level of the LM, and hence, must reflect an external origin of the magma (intrusion). The LA14 composition is more consistent with that of a higher temperature, lower crustal melt (e.g. compare Skjerlie \& Johnston 1996). LA14 is interpreted to be a sample of the intrusive magma from below, whilst the remaining heterogeneous LM matrix is interpreted as representing highly contaminated magmas which formed through physical and chemical mingling of the intrusive magma and country rocks. The abundant enclaves are preserved country rock fragments. Reaction/assimilation features commonly observed in the LM enclaves attest to the extensive interaction between the melt and the country rocks. There are no chilled margins, nor are there extensive contact metamorphic effects to indicate a large temperature gradient at the contact. A viscous, magmatic flow in the LM is inferred from a general concordancy of the strike of lithologic zones in the outcrop and in the orientation of the long axes of the enclaves (Fig. 9; Rutishauser 1972).

Magma transport in the crust during a melting event is apt to vary considerably depending on position and age within the system. One way of evaluating the competing effects of bulk transport versus porous media flow is the size of the MT number. Using this approach to understand the transport of melt (similar to LA14 in composition) through LM modelled as a MRZ of $\sim 30 \mathrm{~km}$ in diameter at a melt fraction of 0.5 , which are broadly consistent with field observations, shows that melt transport by porous flow would become dominant over that by bulk flow as effective particle size becomes larger than $\sim 3.5 \mathrm{~cm}$ (Fig. 3d). This appears to be on the order of the size of pieces which form as a larger enclave breaks up (see Fig. 7A) and therefore, is consistent with the field evidence as initiation of melt flow through an MRZ should start from the breakup of county rocks. Hence, melt is predicted to percolate through the migmatites, rather than (or in addition to) being transported by a bulk movement of the LM. This also provides the possibility of separating the melt ahead of the LM, resulting in the GG.

\section{Conclusions}

Mid-crustal migmatites are a common feature in high-grade metamorphic terrains. They may be the feeder zones for upper-level granite plutons in which magma from a deeper level is both the heat source and a reactive agent.

Predominantly porous-media flow could transport the melt through the hot feeder zone, which acts as a reaction vessel in 
which the deeper-level magma interacts with the country rocks to form an upper-level magma.

A dimensionless number analysis of the possible melttransport processes shows that porous flow will be the dominant mechanism for the melt transport through a $30-\mathrm{km}-$ diameter feeder zone at a melt fraction of $0 \cdot 5$, such as the LM in the Aar massif, if particle size is larger than $\sim 3.5 \mathrm{~cm}$.

The model of the LM as a feeder zone for the nearby GG, with which they have a temporal and chemical link, is supported by the evidence in the LM for a deeper-level magma. The observed reaction and assimilation, as well as the structural concordance, is consistent with solid-laden viscous flow of magma in the migmatites.

\section{Acknowledgements}

We thank Jürgen Abrecht and Clark Johnson for helpful discussions. Critical comments by M. Crawford, R. Weinberg and two anonymous reviewers on the earlier drafts were very helpful. Constructive comments by M. Brown and A. Whittington helped in producing a greatly improved final draft. We also thank the organisers of the Hutton V symposium for making it possible for us to present this contribution. We gratefully acknowledge the supports of NSF grants, GER-9450125 to LPB and SNO, OPP-9814332, OCE-9711575 and EAR-9725158 to BDM, and EAR-9257160 to LPB.

\section{References}

Allibone, A. H. \& Norris, R. J. 1992. Segregation of leucogranite microplutons during syn-anatectic deformation-an example from the Taylor Valley, Antarctica. Journal of Metamorphic Geology, 10, 589-600.

Biot, M. A. 1961. Theory of folding of stratified viscoelastic media and its implications in tectonics and orogenesis. Geological Society of America Bulletin 72, 1595-620.

Bird, R. B., Stewart, W. E. \& Lightfoot, E. N. 1960. Transport Phenomena. Chichester: John Wiley \& Sons.

Brown, G. C. \& Mussett, A. E. 1993. The inaccessible earth, 2nd edn. London: Chapman and Hall.

Brown, M. 1979. The petrogenesis of the St. Malo Migmatite Belt, Armorican Massif, France, with particular reference to the diatexites. Neues Jahrbuch für Mineralogie Abhandlungen 135, 48-74.

Brown, M. 1994. The generation, segregation, ascent and emplacement of granite magma: the migmatite- to crustally-derived granite connection in thickened orogens. Earth-Science Reviews 36, 83-130.

Brown, M. \& Solar, G. S. 1999. The mechanism of ascent and emplacement of granite magma during transpression; a syntectonic granite paradigm. Tectonophysics 312, 1-33.

Cathles, L. M. 1975. The viscosity of the Earth's mantle. Princeton, NJ: Princeton University Press.

Clemens, J. D., Petford, N. \& Mawer, C. K. 1997. Ascent mechanisms of granitic magmas: causes and consequences. In Holness, M. B (ed.) Deformation-enhanced fluid transport in the Earth's crust and mantle, 145-72. London: Chapman \& Hall.

Cruciani, G., Franceschelli, M., Caredda, A. M. \& Carcangiu, G. 2001. Anatexis in the Hercynian basement of NE Sardinia, Italy: a case study of the migmatite of Porto Ottiolu. Mineralogy and Petrology 71, 195-233.

Dirks, P. \& Hand, M. 1991. Structural and metamorphic controls on the distribution of zircon in an evolving quartzofeldspathic migmatite: an example from the Reynolds Range, central Australia. Journal of Metamorphic Geology 9, 191-201.

Ebadi, A. \& Johannes, W. 1991. Beginning of melting and composition of first melts in the system Qz-Ab-Or- $\mathrm{H}_{2} \mathrm{O}-\mathrm{CO}_{2}$. Contributions to Mineralogy and Petrology 106, 286-95.

Ellis, D. J. \& Obata, M. 1992. Migmatite and melt segregation at Cooma, New South Wales. Transactions of the Royal Society of Edinburgh: Earth Sciences 83, 95-106.

Fitzsimons, I. C. W. 1996. Metapelitic migmatites from Brattstrand Bluffs, East Antarctica-metamorphism, melting and exhumation of the mid crust. Journal of Petrology 37, 395-414.
Frost, B. R. \& Chacko, T. 1989. The granulite uncertainty principle: limitations on thermobarometry in granulites. Journal of Geology 97, 435-50.

Ghiorso, M. S. \& Sack, R. O. 1995. Thermodynamic model for the interpolation and extrapolation of liquid-solid equilibria in magmatic systems at elevated temperatures and pressures. Contributions to Mineralogy and Petrology 90, 107-20.

Greenfield, J. E., Clarke, G. L., Bland, M. \& Clark, D. J. 1996. In-situ migmatite and hybrid diatexite at Mt Stafford, central Australia. Journal of Metamorphic Geology 14, 413-26.

Gupta, L. N. \& Johannes, W. 1986. Genetic model for the stromatic migmatites of the Rantasalmi-Sulkava area, Finland. Journal of Petrology 27, 521-39.

Henkes, L. \& Johannes, W. 1981. The petrology of a migmatite (Arvika, Varmland, Western Sweden). Neues Jahrbuch für Mineralogie Abhandlungen 141, 113-33.

Holdaway, M. J. 1971. Stability of andalusite and the aluminum silicate phase diagram. American Journal of Science 271, 97-131.

Hollister, L. S. \& Crawford, M. L. 1986. Melt-enhanced deformation - a major tectonic process. Geology 14, 558-61.

Holz, F. \& Johannes, W. 1994. Maximum and minimum water contents of granitic melts: implications for chemical and physical properties of ascending magmas. Lithos 32, 149-59.

Huerta, A. D., Royden, L. H. \& Hodges, K. V. 1996. The interdependence of deformational and thermal processes in mountain belts. Science 273, 637-9.

Jamieson, R. A., Beaumont, C., Fullsack, P. \& Lee, B. 1998. Barrovian regional metamorphism: Where's the heat? In Treloar, P. J. \& O'Brien, P. J. (eds) What drives metamorphism and metamorphic reactions? Geological Society, London, Special Publication 138. London: Geological Society.

Johnson, A. M. \& Fletcher, R. C. 1994. Folding of Viscous Layers. New York, NY: Columbia University Press.

Jung, S., Mezger, K., Masberg, P., Hoffer, E. \& Hoernes, S. 1998. Petrology of intrusion-related high-grade migmatite: implications for partial melting of metasedimentary rocks and leucosomeforming process. Journal of Metamorphic Geology 16, 425-45.

Leal, L. G. 1992. Laminar flow and convective transport processes. Scaling principles and asymptotic analysis. Boston: Butterworth-Heinemann.

Leitch, A. M. \& Weinberg, R. F. 2002. Modeling granite migration by mesoscale pervasive flow. Earth and Planetary Science Letters 200, 131-46.

Marsh, B. D. 1982. On the mechanics of igneous diapirism, stoping, and zone melting. American Journal of Science 282, 808-55.

Marsh, B. D. 1984. Mechanics and energetics of magma formation and ascension. In Boyd, J. F. R. (ed.) Explosive volcanism: inception, evolution, and hazards, 67-83. Washington, DC: National Academy Press.

Marsh, B. D. 1989. On convective style and vigor in sheet-like magma chambers. Journal of Petrology 30, 479-530.

Marsh, B. D. 2002. On bimodal differentiation by solidification front instability in basaltic magmas, part 1: basic mechanics. Geochimica et Cosmochimica Acta 66, 2211-29.

Mazurek, M. 1992. Phase equilibria and oxygen isotopes in the evolution of metapelitic migmatites: a case study from the Pre-Alpine basement of Northern Switzerland. Contributions to Mineralogy and Petrology 109, 494-510.

Mengel, K., Richterb, M. \& Johannes, W. 2001. Leucosome-forming small-scale geochemical processes in the metapelitic migmatites of the Turku area, Finland. Lithos 56, 47-73

Miller, C. F., Watson, E. B. \& Harrison, T. M. 1988. Perspectives on the source, segregation and transport of granitoid magmas. Transactions of the Royal Society of Edinburgh: Earth Sciences 79, 135-56.

Montel, J. M. \& Vielzeuf, D. 1997. Partial melting of metagreywackes, Part II. Compositions of minerals and melts. Contributions to Mineralogy and Petrology 128, 176-96.

Obata, M., Yoshimura, Y., Nagakawa, K., Odawara, S. \& Osanai, Y. 1994. Crustal anatexis and melt migrations in the Higo metamorphic terrane, west-central Kyushu, Kumamoto, Japan. Lithos 32, $135-47$.

Olsen, S. N., Johnson, C. M., Beard, B. L. \& Baumgartner, L. P. 2000. New U-Pb zircon data and constraints on the age and mode of migmatization in the Aar Massif, Central Alps. European Journal of Mineralogy 12, 1245-60.

Palmeri, R. 1997. P-T paths and migmatite formation: an example from Deep Freeze Range, northern Victoria Land, Antarctica. Lithos 42, 47-66.

Patino Douce, A. E. \& Harris, N. 1998. Experimental constraints on Himalayan anatexis. Journal of Petrology 39, 689-710. 
Petford, N., Cruden, A. R, McCaffrey, K. J. W. \& Vigneresse, J. L. 2000. Granite magma formation, transport and emplacement in the Earth's crust. Nature 408, 669-73.

Petford, N. \& Koenders, M. A. 1998. Granular flow and viscous fluctuations in low Bagnold number granitic magmas. Journal of the Geological Society of London 155, 873-81.

Phillips, O. M. 1991. Flow and reactions in permeable rocks. Cambridge: Cambridge University Press.

Rapela, C. W., Baldo, E. G., Pankhurst, R. J. \& Saavedra, J. 2002. Cordierite and leucogranite formation during emplacement of highly peraluminous magma: the El Pilón Granite Complex (Sierras Pampeanas, Argentina). Journal of Petrology 43, 1003-28.

Rutishauser, H. 1972. Die quantitative Erfassung von Migmatiten im Aufschlußbereich. Unpublished Ph.D. thesis. University of Bern.

Sakuma, S. 1953. Elastic and viscous properties of volcanic rocks and high temperatures. Part 3. Osima lava. Earthquake Research Institute Bulletin 31, 291-303.

Sawyer, E. W. 1996. Melt segregation and magma flow in migmatites: implications for the generation of granite magmas. Transactions of the Royal Society of Edinburgh 87, 85-94.

Sawyer, E. W., Dombrowdki, C. \& Collins, W. J. 1999. Movement of melt during synchronous regional deformation and granulitefacies anatexis, an example from the Wuluma Hills, central Australia. In Castro, A., Fernandez, C. \& Vigneresse, I.-L. (eds) Understanding granites; integrating new and classical techniques, 221-37. London: Geological Society of London.

Schaltegger, U. 1993. The evolution of the polymetamorphic basement in the Central Alps unravelled by precise U-Pb zircon dating. Contributions to Mineralogy and Petrology 113, 466-78.
Skjerlie, K. P. \& Johnston, D. A. 1996. Vapour-absent melting from 10 to 20 kbar of crustal rocks that contain multiple hydrous phases: implications for anatexis in the deep to very deep continental crust and active continental margins. Journal of Petrology 37, 661-91.

Thompson, A. B. 1999. Some time-space relationships for crustal melting and granitic intrusion at various depths: In Castro, A., Fernandez, C. \& Vigneresse, J.-L. (eds) Understanding granites; integrating new and classical techniques, 7-25. London: Geological Society of London.

Thomson, J. A. 2001. A counterclockwise P-T path for anatectic pelites, south-central Massachusetts. Contributions to Mineralogy and Petrology 141, 623-41.

Vielzeuf, D. \& Montel, J. M. 1994. Partial melting of metagreywackes. Part I. Fluid-absent experiments and phase relationships. Contributions to Mineralogy and Petrology 117, 375-93.

Viruete, J. E. 1999. Hornblende-bearing leucosome development during syn-orogenic crustal extension in the Tormes Gneiss Dome, NW Iberian Massif, Spain. Lithos 46, 751-72.

Weinberg, R. F. 1999, Mesoscale pervasive felsic magma migration: alternatives to dyking. Lithos 46, 393-410.

Wernicke, B., Friedrich, A. M., Niemi, N. A., Bennett, R. A. \& Davis, J. L 2000. Dynamics of plate boundary fault systems from Basin and Range geodetic network (BARGEN) and geologic data. GSA Today 10, 1-7.

Wickham, S. M. 1987. Crustal anatexis and granite petrogenesis during low-pressure regional metamorphism: the Trois Seigneurs Massif, Pyrenees, France. Journal of Petrology 28, 127-69.

Wyllie, P. J. \& Tuttle, O. F. 1964. Experimental investigation of silicate systems containing two volatile components. Part III: The effects of $\mathrm{SO}_{3}, \mathrm{P}_{2} \mathrm{O}_{5}, \mathrm{HCl}$, and $\mathrm{Li}_{2} \mathrm{O}$, in addition to $\mathrm{H}_{2} \mathrm{O}$, on the melting temperatures of albite and granite. American Journal of Sciences 262, 930-9.

SAKIKO N. OLSEN and BRUCE D. MARSH, Department of Earth and Planetary Sciences, Johns Hopkins University, Baltimore, MD 21218, USA.

e-mail: olsen@jhu.edu; bmarsh@jhu.edu

LUKAS P. BAUMGARTNER, Institute for Mineralogy and Geochemistry, University of Lausanne, CH-1015 Switzerland.

e-mail: lukas.baumgartner@img.unil.ch

MS received 5 September 2003. Accepted for publication 9 May 2004. 